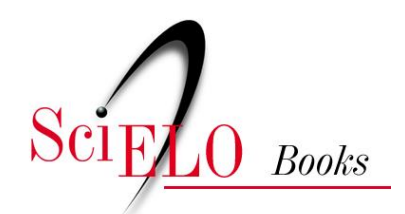

\title{
Jorge, internacionalmente Amado
}

\author{
Sudha Swarnakar
}

SWARNAKAR, S. Jorge, internacionalmente Amado. In: SWARNAKAR, S., FIGUEIREDO, ELL., and GERMANO, PG., orgs. Nova leitura crítica de Jorge Amado [online]. Campina Grande: EDUEPB, 2014, pp. 14-33. ISBN 978-85-7879-328-9. Available from SciELO Books $<$ http://books.scielo.org $>$.

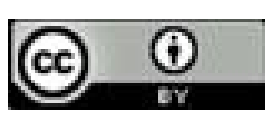

All the contents of this work, except where otherwise noted, is licensed under a Creative Commons Attribution $\underline{4.0 \text { International license. }}$

Todo o conteúdo deste trabalho, exceto quando houver ressalva, é publicado sob a licença Creative Commons Atribição 4.0.

Todo el contenido de esta obra, excepto donde se indique lo contrario, está bajo licencia de la licencia $\underline{\text { Creative }}$ Commons Reconocimento 4.0. 


\title{
Jorge, Internacionalmente Amado
}

Sudha Swarnakar

\author{
"É um paradoxo, mas ele conseguiu trans- \\ formar o regional em universal."
}

(Bruno Barreto)

Bruno Barreto's words call our attention to the universality of Amado's writing that combines well to the thematic title of the Centenary Celebration of Jorge Amado "JORGE, INTERNACIONALMENTE AMADO"' which I select as the title of this essay. Proud and pleased, I see how this event gathered people from all sort; academic, researchers, students, dramatists and general public. This multiplicity of group shows on one hand the popularity Amado enjoyed with his multiple identities; writer, journalist, historian, communist party leader, young rebel, member of Academia Brasileira de Letras etc., and on other hand, how this multiple identity could attract people from different opinion and liking.

Fifty years ago, it would have been unimaginable to talk about Amado in such an open way. Celebrating Centenary of Jorge Amado, today, I recall Claude Guméry-Emery who said:

Hoje é fácil elogiar Jorge Amado, mas não se deve esquecer que em outros tempos isso levaria à cadeia, da mesma maneira como o escritor 
baiano foi parar na prisão pelas idéias que sempre defendeu, e que seus livros foram queimados em praça pública, em auto de fé, como se o fogo queimasse as idéias. (p.74) ${ }^{2}$

The new generation of Brazil has no idea that similar to other leftwing writers, both in Brazil and in other parts of world great writers like Jorge Amado paid a heavy price for their political affinity. ${ }^{3}$ During my interview with Jorge Amado when I expressed my desire to see his manuscripts and letters, his whole expression was suddenly clouded by the extremes of emotion as it took him back to his painful past. He said, "o comunista não tem passado minha filha! Minhas cartas, meus livros, todos foram queimados aqui na praça..."

The political persecution also contaminated Brazilian literary opinion. It is not hard to find those who look at him with certain reserve or even scorn. When I was going to England for my doctorate, a colleague of mine, who was professor of Brazilian literature, asked me about my research topic. When I named Jorge Amado, along with other English and American writers, he did not seem content and said "Porque Jorge Amado?" It was my initiation in Brazilian literary world. I had no notion about the reception of Jorge Amado, and also had not known much about this Bahian writer, so I was astonished at the question yet I answered, questioning "Why not Jorge Amado? Today I may use same words but in 
a defying or sarcastic tone "Why not HE?"

According to Eduardo de Assis Duarte Jorge was little discussed by Brazilian critics because they were trained in modernism so they created a resistance to popular literature produced by writers like Jorge Amado. ${ }^{5}$ But Anco Márcio Tenório Vieira, comes close to my opinion as he says "foram quase inexistentes as tentativas de compreender a obra de Jorge Amado na academia." 6

I have dedicated a big part of my research, apart from the doctoral thesis, to his writings and presented Amado to Australians, Canadians, Americans, English and also to Portuguese and Brazilian audience in conferences and discussion panels talking and publishing papers on themes and topics related to Jorge Amado. I confess that I am an admirer of Amado. As a constant reader of his works, with each reading I discover a fascinating world created by stories narrated in a language which does not discourage his readers to enter in the depth of his writing. His humor as well as his satire is so subtle that a reader does not need special command of Portuguese language to understand it. In his writing, the oral and also the non grammatical forms of Portuguese are intermingled so well that the reader does not even note them. His famous character Gabriela’s "Queiro não", "Gosto não" instead of damaging the linguistic quality of text, enhance it as it brings the lyrical beauty to his text.

My reading of Amado has been bit diverted from other critics as I try to present the "lesser known Amado"; 
Amado who is "feminist" as he raises purely female questions such as abortion, rape, female exploitation and discrimination and marriage as any of female writers, Amado whose heroes and heroines are the marginalized or socially excluded, Amado who condemns the use of plastic surgery for beautification, Amado who is an eco-critic as early as 1940 as he talks of the misuse of water and burning of the forests. In a way it is an unbiased reading of these multiple faces of Amado, that presents him as a great Brazilian writer with his humanity and sympathy for marginalized and subalterns one of the reasons for his universal appreciation. According to the updated dictionary by Paulo Tavares Amado's world is crowded with approximately 5000 characters. It is a fantastic world where we find not only imaginary characters but also real people and some of them are still alive. ${ }^{7}$

During my research years, I could see that the writer, who in part, received scorn and coldness of some literary critics in Brazil, was read and admired both by the socialist countries like Italy, Germany, Russia, Hungry and also by capitalist countries like France, United States and England. The critical tone, specifically in Russia, France, Italy and United States was of praise and admiration. The Italian Feminists admirers of Amado decided to rename their "Italian Feminist Club" and since 1977 it is known as, "Tereza Batista Home." One of the reasons behind such universal acceptance of his writing can be explained through Amado himself as in his interview to VEJA (1969, p. 4) he explains: 
Isto se deve ao fato de que busquei ser sempre ser um escritor voltado para os interêsses, os problemas, a realidade brasileira, dando à minha literatura um caráter nacional, além do caráter social que a marca e preside. Sou um escritor brasileiro, não um papel carbono da última moda da Europa ou dos Estado Unidos. A isso deve o interêsse despertado por meus livros, suas traduções e as tiragens dessas traduções. O que toca, atinge e merece a atenção dos leitores estrangeiros é o Brasil, seu chão, seus problemas, sua vida, sua côr, seu ritmo, seu povo. ${ }^{9}$

In Brazilian literary criticism, Amado, along with other northeastern writers, is placed in the category of "regionalista" because his text is set in a specific region of Brazil, Bahia. Amado also agrees with them as he says, "Bahia é meu território físico e moral" $(1969$, p.4) but if we look at his themes and topics we cannot ignore that they are not limited only to Brazil or to his Bahia they are universal. Exploring the abandon street children he reminds his readers of Charles Dickens, discussing female questions; prostitution, abortion, rape and adultery he can be placed along with Zola, Flaubert 
or other female writer as a defender of women. Well known modern German writer Anna Seghers does not miss to see these qualities in Amado and justly names him the "Brazilian Balzac." 10

The universality of themes in Amado's writing also can be seen as a result of his proximity with a number of European writers. For a foreign reader his setting was Brazil or more specifically, his Bahia but not his themes. He tries to raise humanitarian questions as he selected these themes. His literary realism helped him not to be lost in the limits of "regional" but to use it as a base, as a platform to denounce social and political absurdities and see them as universal problem:

Não nos pretendíamos modernistas, mas sim modernos: lutávamos por uma literatura brasileira que, sendo brasileira, tivesse um caráter universal; uma literatura inserida no momento histórico em que vivíamos e que se inspirava em nossa realidade, a fim de transformá-la.

(AMADO In RAILLARD, 1992, p. 36)

This universality of focus makes him one of the most read and admired Brazilian writers out of Brazil. ${ }^{11}$ In Tereza Batista, cansada de Guerra Amado depicts the marginalized underworld of prostitution which in no way is limited 
to Brazilian reality. In many ways this novel seems to share the sensibility of not only Emile Zola but also of the American novelist Stephen Crane as it makes one recall Crane's depiction of Bovary slums and Maggie in his novel Maggie: A Girl of Streets. ${ }^{12}$

Though his novels were very well received by both Brazilians foreigners, the critical opinion has been divided from the very beginning. In general, critics interpreted his success in Europe as an outcome of his political affinity but looking at his novels, their themes, characters and their wide spread universe which is made of Brazilian soil, and which is read by people of all sects, and class, by people of both right and leftist ideology we see that such a view has no justification. His affinity with communist party might have hindered his reputation and influenced his reception in Brazil in beginning of his career but today it cannot be judged only by this singular fact. Translation of his works in fifty different languages and also the adaptation by media (both cinema and T.V. serials) of a number of his novels, along with this year long celebration of his centenary in and out of Brazilian territory ${ }^{13}$ proves that it was more than his communist ideology that appealed his readers. In my personal view, in general, people cared little about it and are taken by his writing which is deeply rooted in his sympathy for the marginalized. His defense for the oppressed never seized as his discussion of exploitation of working class presented in his early novels is substituted with the exploitation of people at margin, the 
subaltern; the woman, the prostitute and the street children, in his later writing.

O país do Carnaval, Amado's first novel, was written when he was a young boy of eighteen. Published in 1931, by publisher Schmidt, it was very well received. Amado had published a collection of poetry $A$ luva and a small novel Lenita as coauthor in 1928 he did not include them in the list of his complete works. May be it was the tone of these early works that made him to discard them as they do not fit in his ideology.

From the very beginning Amado's writing attracted foreign readers. His first novel to be translated in a foreign language was Cacau (1933) which was first translated in Spanish by Hector Miri in 1936 and published by Editorial Claridad in Buenos Aires. Then in same year 1936, it was translated in Russian by David Vigodsky and published in Leningrad. This cycle of translations which started with publication of Cacau continues till today. Amado enjoys the longest list of English-language translators, including James L. Taylor, William L. Grossman, Harriet de Onís, Helen Lane, Margaret Neves, Samuel Putnam and Gregory Rabassa. Barbara Shelby translated many of his novels; $A$ Morte e a morte de Quincas Berro D'Agua (1962; The Two Deaths of Quincas Wateryell, 1965) and his later novels Tenda dos Milagres (1969; Tent of Miracles, 1971), Tereza Batista, Cansada de Guerra (1972; Tereza Batista: Home from the Wars, 1975), Tietá do Agreste (1977; Tietá, the Goat Girl, 1979), O sumiço da santa (1988). 
It is also important to note that the translated versions of his works have been published mainly by well known publishers in world; Alfred Knopf in United States, "Progress Publishers" in Soviet Union which was before known as "Foreigner Publishers", Pipper and Volk und Welt in Germany, Gallimard in France, Lousada in Argentina and in Portugal mainly by Lyon de Castro. Apart from this, from very beginning his works called attention of publishers in Iran, Arabian countries, Lebanon, China and Vietnam that resulted in translations of his novels in languages like Persian, Arabic, Lebanese Chinese and Vietnamese. The popularity of his work in this non-European world can be seen through the translation of Seara Vermelha in Hanoi in Vietnamese soon after it was published in Brazil. It appears that it was the suffering of the people in draught ridden land that made it more appealing for the Asian readers.

Unlike any Brazilian writers, many of Amado's novels, with strong Brazilian flavor, were written in foreign lands. In 1988 he said "Infelizmente eu não posso escrever um livro no Brasil. Para trabalhar eu preciso fugir." ${ }^{14}$ Two of his novels, Subterrâneos da Liberdade and O Sumiço da Santa were written in Paris. Tieta do agreste was written in London. His displacement to these European capitals were not merely the result of his persecution by Brazilian dictatorial regime but also were motivated by his need to have privacy and freedom. In his interview to Antônio Roberto Espinosa he explains:

Tieta do Agreste escrevi em Londres, 
no ano de 79, e só foi possível fazer esse livro porque estava disposto a fazer como fiz com Tocaia Grande, passei um ano trancado dentro de uma casa, fugindo de casa em casa; porque estive trancado numa casa nova do João, estive trancado numa casa lá no Maranhão, quando descobriram eu tinha que ir para outra lá em Petrópolis, que passei mais um ano na serra, sem sair [...]. ${ }^{15}$

Amado's popularity, in part can be attributed to the media adaptation. His work has been constantly been adapted for film, television, theater, as well as for comics in Brazil, Portugal, France, Argentina, Sweden, Germany, Poland, the former Czechoslovakia, Italy and USA. Among the directors who have adapted his novels for film and television presentations are Walter George Durst, Alberto D’Aversa, Marcel Camus, Nelson Pereira dos Santos, Carlos Diegues, Bruno Barreto, Aguinaldo Silva and Luiz Fernando Carvalho. Glauber Rocha and João Moreira Salles made documentaries about Jorge Amado.

A number of Amado's novels have been successfully transformed in films or T. V. soap operas. Recently, to celebrate his centenary, T. V. Globo presented a newer version of his very popular novel Gabriela, cravo e canela. On 15 Sep- 
tember 2012, In Salvador, the famous drama society of Bahia "Companhia Baiana de Patifaria" presented the first dramatic version, by dramatist Claudio Simões, of Jorge Amado's novel O sumiço da Santa. Though as a literary critic I see and argue that these media productions have damaged the literary value of his work but I cannot deny that they helped in taking this writer to a much wider public. ${ }^{16}$ Calling our attention to the role of media Amado says:
A adaptação de qualquer obra de um autor é sempre uma violência, mas considero as versões de meus ro- mances para a televisão muito posi- tivas, porque levam a obra a milhões de pessoas que não leriam o livro. ${ }^{17}$

I agree, Amado has reason as people who had no access to his books or who had no ability or time to read his novels could familiarize with his works by these media productions. Apart from this his novels also inspired the musical notes and the plot for Samba. The cinematic transformation of his work projected Amado more as a notorious writer and very few will recall today that as most voted congressman he wrote a bill for religious freedom which was approved in 1945 by Brazilian Congress.

A writer with such wide spread readership, Amado was not worried about the future of his works. In an interview given to Veja (17 September, 1969, p. 6) he said: 
Se minha literatura tiver algum valor artístico e humano, permanecerá. Se não tiver, desaparecerá. Mas, de uma ou outra maneira, terá exercido seu papel no tempo presente. $\mathrm{O}$ fato de que no futuro não existam os problemas de agora não invalida forçosamente a literatura que trata desses problemas nos dias de hoje. O importante é que a literatura atual denuncie a existência dos problemas e contribua para que sejam superados.

Today, after forty four years, with celebrations of his birth centenary in different parts of world, we see the truth behind these concluding words. He is more alive today than ever before. With 20 million of his books sold in 55 countries, Amado today is a literary phenomenon.

Apart from 25 novels, Amado's vast writing carrier comprises of memoirs, biographies, chronicles, poems and children's story. Few of his readers know this face of Amado. For me his long story Gato malhado e a andorinha Sinha (1976) is a beautiful work of children's story also his $\mathrm{O}$ menino grapiuna (1982), a mixture of history and memory, presented in style of autobiography with simplicity and clarity, is his great contribution. The narrative technics used by Amado in these works hold his reader from the first page itself.

Though Amado had lived in a number of coun- 
tries and his works also have been familiar to many of us, few non Brazilians know about Amado's racial identity. During my research I was reading Gregory Rabassa's criticism on Amado and when he referred to Amado as a "Negro writer" I simply accepted it as fact because I also had not seen Amado and had no knowledge about the color of his skin. Moreover, Amado's writing is so sympathetic to the people of color that people who had no opportunity to meet him could easily mistakenly believe that he was black. But when I first met Amado, in Academia de Letras da Bahia, in 1998, during a celebration of "Cinquenta Anos de Capitães de areia", I was taken by surprise. The person in front of me was not black as I had imagined but as white as many of Brazilians are. This is how a writer's identity which differs from his racial, cultural, ethnical or religious identity can be confusing. Similar confusion was created about his birthplace by French publishers. In his interview to journalist Antônio Roberto Espinosa Amado gives details of his birth to clear this confusion, affirming his birth place the small village of Ferradas in a rural area of Bahia:

JA - Eu quero falar um pouco também sobre o meu nascimento porque há uma coisa controvertida. Há notícias diferentes, erradas. Há muitíssimos anos, na Enciclopédia Larousse, da França, existe um verbete que me dá como nascido em Piranji. Piranji é 
uma coisa que não existe mais. Deve existir outro no Brasil, porque aquele teve que mudar de nome, passou a ser Itajuípe. Outro dia, num texto que escrevi para uma revista que dedicou um número a mim, a Vogue, eu disse que não nasci em Piranji, ao contrário, Piranji eu vi nascer. Eu assisti ao seu nascimento, desde as primeiras casas que foram construídas.

Em geral, me dão como nascido em Ilhéus, o que é muito compreensível, pois eu fui pra Ilhéus com um ano, ou, para ser exato, com um ano e cinco meses, pois fui pra lá em janeiro de 14 e nasci em agosto de 12. Mas eu nasci realmente numa fazenda de cacau que meu pai estava montando, perto de um arraial chamado Ferradas, distrito do município de Itabuna. O nome da fazenda era Auricídia... hoje, o arraial cresceu, chegou lá, chegou até a casa onde nasci. Aliás, faz poucos anos, eu estive lá e a população foi muito generosa comigo, muito cordial, todo mundo me esperando na rua...

Sou nascido em Ferradas, distrito 
de Itabuna, sou itabunense, ou seja, sou um grapiúna da região do cacau. Mas Ilhéus também é minha cidade no sentido de que é o lugar onde eu vivi a minha infância - a infância, um tempo muito importante na vida da gente. E também a minha adolescência, as férias. Ilhéus é uma cidade extremamente ligada à minha vida, como todo o sul da Bahia, toda a região do cacau. Itabuna fica a 25 quilômetros de Ilhéus. Quando estava em Ilhéus, ia pra Itabuna sempre. Quando morreu meu irmão Jofre, nós fomos pra Itabuna porque minha mãe não quis ficar em Ilhéus. Passamos lá um ano e tanto, foi quando nasceu meu irmão Joelson, que é médico e mora em São Paulo. Dos três irmãos, o único nascido em Ilhéus é James. Assim, eu sou, ao mesmo tempo, um menino de Itabuna e Ilhéus $[. . .]^{18}$

Amado's simplicity and receptive nature is admired by all of us who had the privilege to meet him in person. Miriam Fraga ${ }^{19}$ (p.77): comes close to my opinion as she says: 
Amado não conhecia limites: além das apresentações, dos prefácios, das indicações para prêmios, com a maior discrição, quase em surdina, ele sempre dava um jeito de abrir as portas, de facilitar as coisas, de aplainar os caminhos. E toda vez com a mesma simplicidade, modestamente, como se estivesse cumprindo uma obrigação.

Raros, muito raros os escritores, artistas ou simplesmente amigos que, de um modo ou de outro, não se fizeram credores de sua generosidade.

I witnessed this generosity of great master who opened doors of his home to a stranger and allowed me not only to have an interview with him but also made me see the simplicity of his nature and the greatness of his heart. To meet and talk to Amado is the biggest achievement of my life in Brazil. Celebrating one hundred years of Amado, I am proud to offer my unpublished interview to the Brazilian readers in my upcoming book on Amado. Initially he had agreed for a 20 minutes interview but the time passed, I was with him for almost 2 hours and 30 minutes.

In his interview given to VEJA magazine (1969, p. 7) Amado says, "Minha casa esta sempre cheia de gente que 
estimo e que também me estima." I know the truth behind these words as I remember my visit to his house. I recall the whole scene today as if I am living it again. As a greedy person I was more interested in our talk then anything else. Hence when we were offered coffee and then later the lunch (it was getting close to twelve and Amado has recently recovered from a heart attack) I politely refused to accept it because I did not want to spend these precious moments of my life drinking or eating. What I wanted was to talk to him and I left his house extremely satisfied but without a drop of water and I could feel that it hurt his Bahian hospitality. He repeatedly said "Ela esta indo seca da nossa casa" he did not know the precious food I had received that day in his house.

I conclude my homage to this great Brazilian writer with following citation from Claude Guméry-Emery (p. 74) who says:

Com Jorge Amado aprendemos a conhecer, respeitar, amar, compartilhar a cultura afro brasileira, a culinária, a capoeira, o candomblé. Aprendemos a conhecer, respeitar, amar o outro, a identidade do outro, a cultura do outro, seja ele quem for.

Muitas pessoas que criticaram o escritor baiano hoje em dia reconhecem que ele abriu caminhos de compreensão, de tolerância, de soli- 
dariedade, pela via literária, tanto no Brasil como no exterior. Jorge Amado sempre exaltou as forças de vida (o eros) contra as forças de morte (o thánatos). Não é um escritor apenas baiano ou brasileiro; é um escritor universal que falou de problemas universais. ${ }^{20}$

After hundred years of his birth we can be certain of one thing that though Amado is truly a Bahian or Brazilian writer but he is limitless, he is universal and "Internationally Loved".

\section{Notas:}

\section{(Endnotes)}

1 In November, 2012 my research Group (GT) "Estudos Comparativos Interculturais" with a support from Associacao Brasileira de Estudos Comparativos - ABRAEC and PPGLI, Departamento de Letras e Artes - Universidade Estadual da Paraiba, celebrated hundred years of Jorge Amado. The event was very aptly titled "JORGE: O INTERNACIONALMENTE AMADO" focusing on Amado's reception in world and bringing forward new ways to look at this great Brazilian writer. During the opening ceremony I had privilege to share MY AMADO with the audience. This article is framed on the lecture I delivered at this occasion.

2 see Caderno de Leituras: A Literatura de Jorge Amado. (Org. Norma 
Seltzer Goldstein) Campanhia da Letras, 1999, p. 74. Also available on cite http://www.jorgeamado.com.br/professores/03.pdf . Hereafter cited as

\section{Caderno de Leituras: A Literatura de Jorge Amado.}

3 I recall specifically Ezra Pound the famous American critic and poet who went through more severe political persecution by American government because of his leftist ideology.

4 For details see SWARNKAR, Sudha, Fallen Woman in Twentieth Century English and Brazilian Novels: A Comparative Analysis of D. H. Lawrence and Jorge Amado. Ph. D. Thesis. University of Warwick, England, 1998.

5 Eduardo de Assis Duarte, "Eles criaram, então, uma certa resistência a uma literatura popular como a dele, que é herança das narrativas do século 19, do romantismo, e que dialoga com o público" em Diogo Guedes, "Jorge Amado segundo a crítica literária" em Jornal do Commercio,04/08/2012.

6 - For details see Diogo Guedes, "Jorge Amado segundo a crítica literária" em Jornal do Commercio, 04/08/2012.

7 For details see http://www.correio24horas.com.br/colunistas/detalhes/ artigo/nelson-cadena-personagens-de-jorge-amado.

8 This branch of Italian Feminist Club is situated in the old palazzo on Via Ragabella in Milan, Italy.

9 Though some words are written differently today, the spelling has been maintained as it was in the 1969 edition of Veja.

10 For details on Amdo's reception in Germany see Armbruster, Claudius., O ciclo do cacau de Jorge Amado, a politica, a literatura e a recepção alemã. wnm.goethe.de > Principal > Eventos > Metamorfoses do Cacau accessed on 5th January 2013.

11 For a long time he was the only Brazilian writer read abroad. Today though Clarice Lispector also enjoys the prestige, Amado loses only in com- 
parison to Paulo Coelho.

12 In his novel Maggie: A Girl of Streets (1900) Stephen Crane depicts the famous Bovary slum of New York city where girls like Maggie were raised and abused.

13 I myself participated in a number of centenary celebrations. Presented papers in September in "100 Anos de Jorge Amado: História, Literatura e Cultura" in Ilhéus and in November in "Coloquio Internacional 100 Anos de Jorge Amado: O escritor, Portugal e o Neoliberalismo" organized by CLEPUL in Lisbon, Portugal.

14 See the link: http://www.quemdisse.com.br

15 The interview was given in July 1981 to journalist Antônio Roberto Espinosa for Caderno de Literatura Comentada, Editora Abril, the article was published with the title "É PRECISO VIVER ARDENTEMENTE". Here after cited as "É PRECISO VIVER ARDENTEMENTE".

16 See SWARNAKAR, Sudha, "The Filmic adaptation of Gabriela" (2011) A paper presented at LASA 2011, Toronto, Canada; SWARNAKAR, Sudha, "Quantas Gabriela(s): Fifty years of Gabriela" a paper presented and published in the $\mathrm{CD}$ of proceedings of "Colóquio Internacional 100 ANOS DE JORGE AMADO: História, Literatura e Cultura", Universidade Estadual de Santa Cruz, Ilhéus, Brazil, September, 2012.

17 Amado's comment, after he watched the media adaptation of the novel in video in Paris, in 1989.

18 See "É PRECISO VIVER ARDENTEMENTE".

19 Caderno de Leituras: a literatura de Jorge Amado, p. 74.

20 Caderno de Leituras: a literatura de Jorge Amado, p. 74. 